\title{
DEVELOPING ICT MATERIAL TO ENHANCE EFL TEACHERS PERFORMANCE IN ELT CLASSROOM
}

\author{
Siswandi \\ State Islamic University of Sultan Syarif Kasim Riau, Indonesia \\ siswandi@uin-suska.ac.id
}

\begin{abstract}
This paper has identified an exciting future in which the nature of English as a subject is radically changed, embracing new literacies as a focus and a means for learning and teaching. It has also discussed the factors that impede progress. However, this does not mean that our training of future teachers should present the role of ICT in the teaching of English as limited to that of enhancement, providing a tool to support traditional approaches to the teaching and learning of English. On the contrary, it is essential that we encourage student, teachers to appreciate the powerful impact of ICT on English as a subject, the diversity of texts, uses of literacy and means to facilitate teaching and learning it provides. It is therefore essential that student teachers are aware of their potential to transform learning in their classrooms. By supporting them in gaining the knowledge, confidence and critical awareness to recognize the potential of ICT, we may enable them to provide a vibrant and dynamic English curriculum and embrace further change in the future.
\end{abstract}

Keywords: ICT materials, EFL teachers performance, ELT Classroom.

\section{A. Introduction}

In the contemporary world of rapid developments in technology and in the nature of literacy practices, the relationship between English and ICT within the school curriculum lies at the heart of current educational debates. The debate brings together arguments over the nature of each of these subjects and their presentation within the curriculum, as well as discussions about the purpose, priorities and future of the education system itself. In spite of this, it is only in the last few years that practitioners, theorists, and researchers have begun to pay serious attention to the challenges and opportunities that new technology presents for EFL teachers and English teaching (Lankshear and Knobel, 2003a; Andrews, 2004).

This paper examines issues involved in the complex and changing relationship between ICT and ELT and their implications for classroom teaching. The EFL teachers/learners enter teacher education with a wide range of experiences and levels of expertise in ICT. The aim is to enable all EFL teachers/learners to be aware of these important issues and have the skills, knowledge and critical understanding to respond confidently and positively to the opportunities 
presented by ICT in their present and future teaching of English. The paper therefore begins with an analysis of the changing nature of literacy in the light of current developments in technology. Then, They explore different interpretations of the role of ICT in the teaching of English. This leads into consideration of implications for ICT in meeting EFL learners/teachers' needs and particular issues for teacher educators.

\section{B. Discussion}

\section{The Concept and definition of ICT project}

The breakthrough of Information and Communication Technologies (ICTs) has utterly shaped our modern life. ICT is the term that is currently used worldwide to describe new technologies which depend mainly on computers nowadays. Even the traditional technologies such as radio, television and telephone are considered as ICTs. The United Nations Development Programme (UNDP, 2005) defines ICTs as:

„basically information-handling tools - a varied set of goods, applications and services that are used to produce, store, process, distribute and exchange information. They include the 'old' ICTs of radio, television and telephone, and the 'new' ICTs of computers, satellite and wireless technology and the Internet. These different tools are now able to work together, and combine to form our 'networked world' a massive infrastructure of interconnected telephone services, standardized computing hardware, the internet, radio and television, which reaches into every corner of the globe e.
Technological innovation has changed the social, political, economic, and cultural of life since the end of the Cold War (Taylor, 2001). Information and communication technologies (ICTs) have been instrumental in social transformations, from the industrial society of the 20th century to the "network society" of the new age of Informationalism, where even intercontinental neighbors are now one button-push away. Information and communication technologies (ICTs) are a double-edged sword destructive and beneficial to the extreme. Therefore, we have to face this fact and react immediately. We should ask ourselves about its availability and its affordability concerning its cost in our developing countries. In addition, we have to determine its effectiveness and suitability to the different educational contexts.

The Information and Communications Technologies (ICTs) have a vital role in the process of any English language teaching (ELT). Evidently, no one would deny its contributions to the educational field. Especially, to the teaching and learning of English language they have a considerable influence on the way we teach and the content we deliver. The new ICTs are much faster than the traditional ones and it might give an immediate feedback as well as the instant interaction.

The ICTs are potentially more open, affordable to be owned and operated by schools, universities, private institutions, or even by individuals, who can control the process according to the one's own needs and wants for better controlled outcome and quality. 


\section{The use of ICT in ELT Classroom}

The importance of English is not just, in how many people speak it, but in what it is used for. English is the major language of news, internet and information in the world. It is the language of medicine, business and political affairs in some countries, where it has other minor languages. It is the language of science and technology in countries where it is not a native language. Moreover, in the workforce competency in English is required beside the very field of specialization. Therefore, English for us is an evitable language to be taught and learned in our educational institutions if we want to keep in touch with the each other and up-to-date in our information.

Indonesian EFL teachers/learners, and most of schools in Riau Province in general rely on the traditional methods of teaching English as foreign language such as the grammar translation method or audio lingual method neglecting genuine opportunity provided by these modern technologies. As consequence for many factors when our learners/ students leave the school who have studied formal English teaching often remain poor to use the language communicatively (spoken or written) when they encounter authentic situations.

Nowadays, Indonesian EFL teachers of English around the world prefer some form of communicative language teaching (CLT), rather than the traditional methods of English Language Teaching (ELT) which dominate the teacher-centered approach and neglect the student ${ }^{\text {ee }}$ communication skills. The teacher-centered approach depends mainly on the learner's memory and did not care about the authentic use of language. Although, a successful English Foreign Language
(EFL) teacher is not necessarily restricted to one method or another, the ICTs have changed the pace of teaching strategies to suit the goals of his materials and the needs of his students. On the other hand ICTs have given the students many opportunities to practice English in and out the classroom. With the help of the modern technologies they have time and freedom to understand, reflect and analyze what have been exposed to.

Moreover, the ICTs put forward an influential based for efficient education. Now, we need the modern technologies for a better blended method of delivery to create apt teaching techniques to enhance the process of learning English language. ICTs are very motivating, because they help the EFL learners to learn the language which is carefully designed to meet the prescribed goals.

\section{The application of ICT in ELT Classroom}

No doubt, motivation is the cornerstone in the process of acquiring or learning a foreign language; therefore, EFL learners usually have a positive attitude toward computers. Even though, the modern technologies are double-edged sword, their advantages are acknowledgeable over its pitfalls. No doubt, they have significant, positive impacts on ELT, the following are some them:

\section{a. Availability of the Materials}

ICTs are very stimulating because of the availability of the learning materials whether it is computer-based, in the web or on CDs; therefore, the EFL learners can learn at his own pace with a very patient tutor (the machine). Meanwhile, the use of online telecommunications for teaching and learning via the computer in the 
classroom across the world will consolidate the improvement of different academic skills. The availability of images, animation, audio and video clips they help much more in presenting and practicing new language.

\section{b. The EFL learners Attitudes}

ICTs have positive effects on the EFL learners attitudes toward the language teaching and learning. The learners felt more successful in school, were more motivated to learn and have increased self-confidence and selfesteem when using computer-based instruction. This was particularly true when the technology allowed learners to control their own learning.

\section{c. Autonomy of EFL learners}

the learners have the opportunity to choose the element/s of language which they want to focus on meeting their learning strategies or learning styles. Here, the learner-centered approach is supported by these facilities offered by the ICTs while the tradition techniques approaches failed to give such opportunities. The EFL learner feels free to practice the language without fear from the others at their own phase and pace.

\section{d. Authenticity}

ICTs provide authentic learning environment, because the learner can interact with others across the continent are very motivating to the English language learners. Confronting such challengeable situations is the touchstone for using the language in authenticity not artificially. The ICTs as tools for learning are very motivational; however, they are very attractive and accessible.

\section{e. Multifaceted Tools}

No doubt, (ICTs) could successfully contribute to two ends: creating a blend of classroom materials and delivering those materials in multiple ways. They facilitate different activities such as testing, doing exercises and performing different pedagogical tasks or games.

\section{f. Help EFL Teachers}

ICTs help the teacher to prepared, produce, store and retrieve their materials easily and swiftly. The availability of different rich texts, different topics, quizzes, exercises help in saving the teacher"s time. Despite the opportunities and facilities offered by the modern technologies in assisting better teaching, but they do not replace it. So far, the skillful EFL teacher is the only person who is shouldering the responsibility of delivering and achieving the teaching goals.

\section{g. Student-centered}

ICTs help the EFL leaners to write and edit their work in order to produce a well published work. Likewise, computers encourage EFL leaners to do extra work outside the classroom, play language games and, hopefully, gain extra exposure to the language and improve their progress in the language and support the studentcentered concept. Via the computer and the internet the students will be able to communicate with others in different places.

Moreover, ICTs help the shy or the quiet students/leaners who sometimes abstain from asking questions or challenging information to communicate and ask questions. Using modern technologies in the learning environment has been shown to make learning more student-centered and improve the learning process by stimulating teacher/student interaction. Furthermore, ICTs enhance collaborative learning which results in 
higher self-esteem and leaners achievement. They promote critical thinking and student interaction.

\section{h. ICTs in Self-Assessment}

The examinations generally test the reading and writing skills of the EFL learners, totally neglecting the listening and speaking skills, which are indispensable skills for the EFL learners in their future career. The listening capacity can be tested through computer-assisted packages like listening to a dialogue/passage and answering the questions or listening to lectures and then answering short questions or true or false statements. It will enhance their talents for taking international tests because many competitive exams follow such a pattern to test the grasping ability of the learners.

Instructors/ EFL teachers should be aware of modern technologies pitfalls if they want to adopt them in pedagogy. Feenberg (2002) and Yagelski (2005) give their warning for the teachers to study carefully the integration of any newer ICTs into English language arts and literacy teaching as a given advantageous outcomes. The development of new technologies and the decision to integrate them into teaching and learning lives is neither a given conclusion nor following a prearranged route.

Teachers, individually and collectively, have the capacity and the responsibility to influence the development, modification, adoption, and/or rejection of newer technologies. In order to make these critical decisions, they will need to understand not only how to use these technologies, but also the benefits and costs their adoption and integration into English language arts and literacy teaching have the potential to create for teachers, learners, and the broader community.

The EFL teachers should not take up such serious issues childishly without thinking of the consequences. Since best practice in teaching requires that teaching must be definite to individual students, classrooms, and communities. Such decision-making will require additional research on the classroom at local as well as national levels. If the teachers and the learners haven "et got sufficient training to use the new technologies effectively, the process will be frustrating and time consuming. The quality of programs has not yet reached the level of assessing the userse natural spoken language or the appropriateness of use in the context of the situation.

\section{The use of ICT relate into pedagogical concept of ELT}

Evidently, learning materials designed and delivered by modern technologies add quality and value to the teaching/learning environment. They should help develop basic thought processes such as critical thinking, analysis, and problem solving. The skillful instructor/EFL teachers knows how to get the maximum benefits from these technologies in during the period or course limited life time.

New materials delivered via the Internet that help with the repetition needed for developing reading, writing, and listening in English can reduce hard work for educators/EFL teachers and can be entertaining for both the teacher and the learner. Actually, modern technologies can facilitate and motivate the teaching and learning process. To obtain a better benefit from the potentials of the ICT, there should be the following: 
a. Every classroom should be equipped at least with a computer and a data show projector to enable the teacher to present the new lesson effectively.

b. There should be a website for the class designed deliberately for pedagogical purposes. Teachers can exploit this site for assigning exercises, homework and in turn the students can respond to the instruction and the feedback would be immediately via the machine.

c. As the feedback is immediate, the learners can identify their strengths and weaknesses and improve on them. As learner autonomy gets momentum, they facilitate individualizing curriculum, permitting them to dictate the pace of learning and widen the sources of information in the required area.

d. It has been widely recognized that connecting the power of ICTs for learning purposes requires that appropriate learning strategies be developed that harmonize effectiveness in learning with the technology role. This recognition underpins the UfI/National Grid for Learning relationship, and

e. General interest in fostering innovation in learning strategies (Kearns \& Papadopoulos 2000:77).

f. Every learners should have an email and he should use his email in sending his assignment and any enquiries to his tutor.

g. The capacity of ICTs to deliver information or to communicate with mass of learners in somewhat entities let the process of learning more suitable for the learners need in time and place without the restrictions of the traditional classroom situations.

The use of ICTs in English language teaching (ELT) has countless benefits. The development in the use of ICT, like language lab, videos, satellite broadcast, videoconferencing and web seminars have support the richness and quality of education both on and off campus. The Distribution of the knowledge and learning with more flexibility supports the slogan, "Any space is a learning space." Therefore, our schools and universities should be equipped with computers and internet services not just tools to learn a language, but they contribute to different aspects of educational development and effective learning.

Recent years have seen a move from the predominance of the printed text to varied sites or textual production, including web-based environments, mobile phones and computer games. Screen-based texts are characterised by varied and densely interwoven multimodal communication, with an increasing emphasis on visual aspects of texts, such as layout, use of font and images, and the incorporation of sound, animation and hyperlinks.

Digital technology has also made it easier to experiment with text production (for example, using multimedia authoring and digital video editing programs) and to communicate rapidly with a range of familiar and unfamiliar audiences, for example through, websites, textmessaging, emailing, instant-messaging and blogging. The affordances of these new texts have implications for our understandings of reading and writing as they enable different kinds of meaning-making (Snyder, 2002; Kress, 2003; Merchant, 2006). The process through which texts are created and accessed may also be different. Screenbased composition involves the juxtaposition of various modes whilst comprehension involves making sense of information from texts which contain multimodal elements and often offer 
varied reading pathways (Burbules, 2002; Kress, 2004; Merchant, 2006).

The relationships and practices which evolve around such texts are particularly significant. For example, the ephemeral nature of digital texts has implications for our notions of authorship (authors may be multiple or obscured) and for our relationships with the information contained within texts. The reader's relationship with websites, for example, may be more dynamic than that with print-based texts; Internetusers may return to sites regularly, or use opportunities for interaction, such as online chat, email and discussion boards, to share their perspectives or associated information with others. The ease of communication with a range of others, both known and unknown, also has implications for the way in which people interact with the world around them. Such opportunities may overcome barriers of time and space, or 'shrink the world' (Tapscott, 1998). As Snyder (2002) notes, such opportunities bring the outside world into the home. Particularly significant here are the opportunities that digital technology affords to pupils.

Digital technology is heavily used by many young people in their lives outside the classroom and they demonstrate familiarity with such forms of communication as essential features of everyday life. Various studies have noted the autonomy and creativity with which young people engage in such practices; much online activity is marked by identity play and textual innovation (Marsh, 2005; Merchant, 2001; Merchant 2005a).

During the integrating process, the nature and content of English language courses are reassessed and specified. These specifications guide teachers about what to teach and what pedagogical knowledge and ICT skills they may need to teach these courses. Shulman describes a framework of teachers' knowledge bases as the following categories (1987)[2]:

1. Content knowledge;

2. General pedagogical knowledge;

3. Curriculum knowledge; and

4. Pedagogical content knowledge

In the list, content knowledge refers to the knowledge of teaching materials which is also what learners are taught; general pedagogical knowledge is related to general teaching issues, such as teaching approaches, classroom management; curriculum knowledge is the "tools of the trade", General pedagogical knowledge and pedagogical content knowledge together justify teachers' decisions on teaching methods and content.

\section{Conclusion}

Teachers' development of ICT literacy has been first revealed by educators and experts, the impact of the teacher is clearly crucial in mediating how ICT is used within the classroom. Most ICT training projects accent teachers' development in technical capabilities in isolation and fail to link teachers' technical capabilities to integrate ICT as a pedagogical tool across curriculum. Fewer training projects aim at developing their cognitive ICT-related capabilities of problem solving and information processing.

The EFL teachers as less competent and confident ICT users are expected to improve their professional performance upon ICT-integrated problem-solving tasks and pedagogical reasoning on such tasks. Once their ICT-related cognitive and technical capabilities increase, they need to blend 
their experience with the capabilities and apply appropriate ICT to their pedagogical approaches and hence are more likely to contribute constructively and efficiently to English Language Teaching (ELT). Use of ICT across curriculum has constructed new beliefs that change the pedagogical reasoning in English teaching. English teachers need to not only possess such basic ICT skills as word processor, PowerPoint, video editor and access to the Internet, but also develop pedagogical knowledge to efficiently integrate ICT into English curriculum. The integration of ICT will lead to diversification not only in English content, contexts and pedagogical methods, but also in teaching environment. ICT will extend the boundary of English teaching and characterize it as interactive, flexible and innovative.

\section{References:}

Abu Naba'h, A. (2009). The Effect of Computer Assisted Language Learning in Teaching English Grammar on the Achievement of Secondary Students in Jordan. The International Arab Journal of Information Technology, Vol. 6, No. 4, October 2009. Available online at http://ccis2k.org/iajit/PDF/vol.6,n o.4/452.pdf .

Azmi, N. (2014). The impact of InfoTech on English language teaching practices, learning achievement and students' perspective transformation. School of Education, Mohamed V University in Rabat- Morocco.

Blake, R. J. (2008). Brave New Digital Classroom: Technology and Foreign Language Learning. Washington, D.C: Georgetown University Press.
Becta. (2005). The challenge of change ICT and e-learning in Further Education. Becta: Author.

Biyaem, Suda. (1997). Learner Training: Changing roles for a Changing World, Educational Innovation for Sustainable Development. 3rd UNESCOACEID International Conference, Bangkok.

Erben, T., Ban, R., \& Castañeda, M. (2008). Teaching English language learners through technology. New York and London: Taylor \& Francis eLibrar.

Freeberg,A.(2002)." Transforming Technology in the Learning Process". Canberra.

Lloyd, M. (2005). Towards a definiti on of the integration of ICT in the classroom. In AARE 2005, AARE, Eds. Proceedings AARE '05 Education Research - Creative Dissent: Constructive Solutions , Parramatta, New South Wales.

UNDP (2005) Promoting ICT for Human Development in Asia: Realizing the Millennium Development Goals, ELSEVIER A Division of Reed Elsevier India Pvt. Ltd.

Richard Andrews (2003) Where Next in Research on ICT and Literacies?, National Association for the Teaching of English, Volume 37, Issue 3 September 2003, Pages 28-41.

Taylor ( 2001) Technology for teaching and learning in higher education contexts: Activity theory and actor network theory analytical perspectives, International Journal of Education and Development using ICT Online 3 (4). 
Youssef, A. B., \& Dahmani, M. (2008).

The Impact of ICT on Student Performance in Higher

Education: Direct Effects, Indirect

Effects and Organizational

Change. 
